\title{
THE CLASSICAL ASSOCIATION OF SOUTH AFRICA: FEBRUARY 1983 - JANUARY 1985
}

\author{
W J Henderson (University of Johannesburg)
}

Previous articles on the history of the Classical Association of South Africa, based on archival material, covered the period from 1908 to $1983 .^{1}$ The present instalment takes this history to the beginning of 1985 .

\section{$1 \quad$ Administration, February 1983-January 1985}

\subsection{General}

The Executive Committee dealt with the proposals made at the previous conference: the theme of the next conference, 'Modern theories of literature and ancient texts' ${ }^{2}$ the principle of bilingualism in CASA notices occasioned by the resignation of Dr P Greenhalgh; ${ }^{3}$ possible short communications by Honours and MA students; ${ }^{4}$ the ways and means of inviting an overseas speaker to the next conference; ${ }^{5}$ the possible re-introduction of the concession to student members to register for three years in advance at a reduced membership fee (abolished due to administrative difficulties); ${ }^{6}$ a pamphlet with information about the Association; $;^{7}$ a member of CASA to be co-opted to the Executive with the specific task of tracing all teachers of Latin and Greek and enrol them as members, and advise the Executive and regional committees on ways to involve teachers effectively in the activities of the Association and assist teachers as much as possible in the interest of Latin and Greek; ${ }^{8}$ the possible re-introduction of the practice of appointing

1 Henderson 2004, 2005, 2006, 2007, 2008, 2010, 2013a, 2014. For the name changes of provinces, cities and universities since 1994, see Henderson 2004:89 n. 3; 2005:109 n.1; 2006:135 n. 6; 2007:109 n. 59.

2 See Henderson 2014:137.

3 Reiterated at the Second Business Meeting, 23 January 1981; see Henderson 2010:111. Dr Greenhalgh had received a notice in Afrikaans. Dr J Atkinson had suggested at the 1981 meeting that the Executive should protect the Secretary by agreeing to a set of ground rules: that important notices (subscriptions, finances, constitutional changes, notices of CASA conferences) were to be made available in English and Afrikaans; that other communications should be provided with a short summary in the other language and an offer to send a full translation if requested.

4 See Henderson 2014:135.

5 See Henderson 2014:135-36.

6 See Henderson 2014:136.

7 See Henderson 2014:136.

8 See Henderson 2014:136-37. 
persons to open the discussions of papers; ${ }^{9}$ and speakers to make copies of their papers available beforehand. ${ }^{10}$

The proposals were discussed by Prof L Baumbach (C) and Dr M Matier (S) in Cape Town on 19 April 1983 and by Prof B de Wet (VC) and Dr R Whitaker (T) on 9 May 1983 in Durban. Prof W J Henderson contributed his views after his return from sabbatical in Italy. All agreed that papers were to be invited on the main theme, but that, as in the past, papers on other themes would also be welcome; in addition, two specialists on modern literary theory should be invited to deliver papers, the Executive to make the selection from a list of possible candidates; and offers to read papers to be submitted before April 1984. Important notices should be in both English and Afrikaans, the preliminary notices for the Rhodes conference to alternate between the two languages, and the agenda and minutes to be in both languages; however, the Secretary could use his discretion in the case of individuals who did not know Afrikaans. MA and PhD (rather than Honours) students ought to be encouraged to present short communications on their research, but this is the responsibility of their supervisors and much would depend on the number of papers offered. Regarding having an overseas scholar at the next conference, it was suggested that each university contribute to the costs of such a visit and in return invite the visitor to deliver a lecture at its campus; the UCT Summer School could be approached to include the speaker in its programme and make a contribution; members of the Executive were requested to submit lists and brief curricula vitae of possible speakers to the Secretary. Any pamphlets of information issued by regional branches should be sent to the Secretary for circulation to the Executive in order to check on what is circulated in the name of the Association; the Secretary, in turn, could send an outline of the aims and objectives of CASA to the regional branches (which was duly done).$^{11}$ It was felt that the tasks of tracing all teachers of Latin and Greek with a view to enrolment as members of CASA, and involving and assisting teachers were best left to the regional branches. Also, the appointment of a full-time PRO was not justifiable, given the Association's limited budget and amount of work; again, regional branches could handle this. Because of a full programme, persons appointed to introduce discussion of the papers should be asked to limit their comments to one or two questions to stimulate discussion. The suggestion that speakers should make copies of their papers available in advance was deemed impractical; at most, speakers could submit an abstract for acceptance and then make their papers

9 See Henderson 2014:138, point 4.

10 See Henderson 2014:138, point 5.

11 Information pamphlet to members, 9 September 1983, explaining the aims of the Association and announcing the Colloquium and next conference at Rhodes University. 
available to the persons introducing the discussion at least a day before presentation. $^{12}$

The Treasurer, Prof Whitaker, presented an interim balance sheet as at 31 December 1983 to the Executive: accumulated assets stood at R5 196, an increase of R1 220 over the previous period. ${ }^{13}$ The Executive met at RAU on 3 July 1984, at 19:30. Those present were Proff Baumbach, G Chapman, Henderson, Whitaker and Dr Matier; Prof De Wet was abroad and sent his apologies. Among the decisions made were that a registration fee of R12 be charged for the conference; that the provisional programme be sent to all speakers to confirm their slots; that speakers no longer be required to submit a summary and short bibliography before their papers were accepted, but that Afrikaans speakers should submit an English summary for the benefit of visitors from overseas; that a second circular with all the necessary information should be sent to all members before the end of August; that from the middle of August to the conference in January Prof De Wet be Acting Chair in the absence abroad of Prof Baumbach; that, in view of the relocation of the 1984 conference to Pietermartizburg, Prof Chapman would withdraw his offer to host the 1986 Colloquium and that Dr Matier would extend an invitation for the Colloquium to be hosted by the University of Durban-Westville; ${ }^{14}$; that provisional agendas be drawn up for the First Business Meeting and the Executive Meeting to be held on 21 January 1985; that the Secretary's provisional reply to Prof F Saayman (see below, 1.6 Latin and Law) be approved and the decision communicated to Prof Saayman; and that the two published HSRC reports on Latin be included in the agenda for the Second Business Meeting and that Prof Henderson remain in contact with the HSRC. ${ }^{15}$ The second circular containing all the relevant information and the provisional programme was sent out on 31 August $1984 .{ }^{16}$

A matter that had occupied the Association from the beginning, namely the spelling of Greek proper names in Afrikaans, finally resulted, after 27 years, in concrete results with the publication of the Lys van Klassieke eiename, published by the Taalkommissie of the Suid-Afrikaanse Akademie (Cape Town 1984). ${ }^{17}$

The Association was deeply saddened by the passing of Prof Suretha Bruwer on 21 October 1983. All who knew her could attest to her enthusiasm, energy, dedication, willingness to undertake tasks and thoroughness in executing

12 Agenda and Reports, 27 April 1983 and 9 May 1983; Henderson to Executive, 16 August 1983.

13 Statement, 1 February 1984.

14 Now incorporated with the University of KwaZulu-Natal.

15 Minutes of Executive Meeting.

16 Second circular, 31 August 1984.

17 See Henderson 2004:92 (3.1), 100 (4.1); 2008:84, 89. For a review, see Smuts 1984c. 
them. She was an asset to the Association, the Department of Latin at Stellenbosch and to Classics in South Africa. ${ }^{18}$ Prof Baumbach sent a letter of condolence on behalf of the Association to her father. ${ }^{19}$

\subsection{Visitors}

Prof Baumbach (C), replying to a circular from the Department of National Education (dated 18 April 1983), submitted a request for approval in principle for extending an invitation to an eminent foreign Classical scholar to deliver a paper at the forthcoming CASA conference in January 1985, give a series of lectures at the UCT Summer School and possibly also to lecture at the different universities in South Africa. She explained that the Executive was still in the process of deciding on a specific person. ${ }^{20}$ However, the Department of National Education was not prepared to discuss the matter without the submission of the name of a particular speaker. The Executive felt that Dr Pat Easterling of Cambridge University would be most suitable, if in fact she could come in January. ${ }^{21}$ Dr Easterling accepted the invitation, but the application for funding from the Department of National Education was unsuccessful. Prof Baumbach approached the universities for contributions to make the visit possible. ${ }^{22} \mathrm{RAU}$, for example, was willing to host Dr Easterling and to make a financial contribution, but required a $\mathrm{CV}$ and schedule, which Prof Baumbach provided. ${ }^{23}$ The plan to have Dr Easterling at the conference was successful. She duly presented a paper at the conference.

Other overseas visitors to UCT and Stellenbosch were Prof K D White (Reading University), who spoke on 'Roman shipping' (24 April); Prof Julian Brown (King's College, London), on 'Roman books and their illustrations' (July); and Sir Ronald Syme (Oxford), on 'Julius Caesar: drama, legend, history' (27 August).

\subsection{Colloquium}

The organiser, Prof Henderson, proposed to the Executive that the Colloquium should take place in June or July 1984 during the winter vacation of the

18 S to Henderson, 12 December 1983, with a letter of condolence from Dr John Percival, Joint Hon. Secr. of the Classical Association in the UK (dated 30 November 1983), and the Secretary's reply, 12 December 1983. Obituaries by Smuts 1984a (with letters of condolence from Percival, Prof Frank Goodyear and Prof John Atkinson) and 1985a.

$19 \mathrm{C}$ to Mr L C Bruwer, 26 October 1983.

20 C to Mrs R Groenewald, Department of National Education, 10 June 1983.

21 S to Henderson, 10 September 1983.

$22 \mathrm{C}$ to Henderson, 16 May 1984.

23 Henderson to C, 28 May 1984; C to Henderson, 5 June 1984. 
universities, but during the Transvaal school term to enable teachers to attend, and that papers be limited to 20 minutes to allow for discussion. This was agreed to. ${ }^{24}$ The organiser sent out a first circular in English and Afrikaans (which cost R10.52 to print) ${ }^{25}$ followed by a semi-final circular setting out the arrangements. ${ }^{26}$ Matters concerning finances (printing of circulars and conference manual, stationery, postage), the registration fee of R10, and the final programme were approved by the Executive; other arrangements (the date 4-6 July 1984, correspondence with the speakers, accommodation, notification of Transvaal schools) were delegated to the organiser. ${ }^{27}$

The main theme, 'Teaching Greek and Latin literature at university' was subdivided into the following sections: aims and objectives, approaches, course content, Latin literature in school, and the use of translation. Most of the talks were published. ${ }^{28}$ A profit of R244.50 was paid into the CASA treasury. ${ }^{29}$ Forty-eight delegates attended the proceedings.

\subsection{Acta Classica}

Since 1982 the journal had been published by CASA, which employed Messrs Tensor Letterset (Pty) Ltd as typesetters and Messrs V\&R Printing Works (Pty) Ltd as printers, both in Pretoria. The change of publishers had presented financial and administrative difficulties, in particular the management of subscribers' accounts, formerly handled by the previous publisher, A A Balkema, and his Rotterdam office for overseas subscribers. The Executive found it necessary to engage the services of Universitas-Books (Pty ) Ltd in Pretoria. The parcelling and posting of the journal were undertaken by the members of the Latin Department at the University of Pretoria and the Classics Department of Unisa. Eighty complete sets of Acta Classica held by Balkema were transported by rail from Cape Town to Pretoria at a cost of nearly R277, and stored in the basement of the Law Library at Unisa. A couple of sets had been sold at a reduced rate and the rest were being kept

24 Henderson to Executive, 16 August 1983, point 3; S to Henderson, 10 September 1983, point 3.

25 'Colloquium 1983'; Henderson to T, 2 February 1984; T to Henderson, 10 February 1984.

26 'Colloquium 1984'; S to Henderson, 3 May 1984; Henderson to C 28 May 1984.

27 Henderson to S, 19 October 1983; C to Henderson, 28 October 1983; VC to Henderson, 31 October 1983; S to Henderson, 1 November 1983; T to Henderson, 3 November 1983

28 Baumbach 1985b, Conradie 1985, Mans 1985, Matier 1985, Saddington 1985, Schoeman 1985, Scholtemeijer 1985, Swanepoel 1985, Van Stekelenburg 1985b, Wakerley 1985; Landman 1986, Lombard 1986, Mezzabotta 1986, Van Ryneveld 1986.

$29 \mathrm{~T}$ to Henderson, 25 September 1984. 
for individuals and exchanges. ${ }^{30}$ Exchange periodicals from May 1982 to May 1983 numbered 55, from May 1983 to June 1984 39, from June 1984 to June 198551 . $^{31}$

\section{$1.5 \quad$ FIEC}

Relations with the international organisation continued to cause concern. In response to a letter from Dr Matier (dated 9 March 1983), the FIEC Secretary, Prof François Paschoud, expressed the wish that the new arrangements made by CASA (i.e. to address all correspondence to the Secretary) ${ }^{32}$ would result in 'more correct' relations with FIEC. He recalled the absence of Prof M Arnheim at Budapest in 1979 and of Prof J M Grové at Helsinki in 1981, both without excuses. Dr Matier was referred to Prof B Hendrickx for the documentation he had sent. ${ }^{33}$ A second letter (in reply to Matier's of 28 April 1983) acknowledged Matier's explanations and the clarification of CASA's position, and looked forward to meeting Prof Baumbach in Dublin. He recommended that CASA appoint a permanent correspondent, someone young (senes non scribunt, he added) and known for 'exactitude'. ${ }^{34}$ Dr Matier replied to Prof Paschoud's letter of 10 May, reporting that he had sent copies of the letter to the members of the Executive, who had all agreed to the appointment of a permanent correspondent, and that he himself had been appointed to this position. ${ }^{35}$ Prof Baumbach represented CASA at the FIEC meeting in Dublin in August 1984, and gave a report on the proceedings. ${ }^{36}$

Affiliation fees to FIEC amounting to R43 in 1981, R58 in 1982, R53 in 1983 and R68 in 1984 were paid. ${ }^{37}$

\subsection{Latin and Law}

Prof Saayman (University of the North) ${ }^{38}$ wrote to the Secretary requesting CASA's views on his university's proposed plan to abolish Latin Special in favour

30 Acta Classica Report; see 2.1 below.

31 Cf. Hasse 1983, 1984, 1985.

32 Minutes of First Business Meeting, 18 January 1983, item 6.3; Henderson 2004:134.

33 Paschoud to S, 3 April 1983.

34 Paschoud to S, 10 May 1983. Indicative of the improved relations were Prof Paschoud's communication that he appreciated Matier's placing a stamp of a steam locomotive on his letter, since he, Paschoud, had visited South Africa in 1979 to see 'un parc d'animaux' and travel on steam locomotives between Bethlehem and Kimberley, and between George and Oudshoorn, of which he had fond memories.

35 S to Paschoud, 29 June 1983; S to Henderson, 11 July 1983.

36 Agenda; Minutes of First Business Meeting, 7.7.

37 Treasurer's Report, p. 3.

38 Merged with the Medical University of Southern Africa (Medunsa) in 2005 to form the University of Limpopo. 
of a three-year study of Latin..$^{39}$ The Secretary undertook to include the query on the agenda of the Executive meeting on 3 July 1984 and report back. However, he gave his personal view as a provisional answer. There was no uniformity of practice at SA universities. At the University of Durban-Westville, for example, students were required to do two years of Latin Special, followed by one year of Latin I, but, under pressure from the Law Faculty, Latin Special had now been reduced to one year, as at Rhodes University and the University of Natal at Durban and Pietermaritzburg. The Association could not prescribe policy to any university. ${ }^{40}$

In response to a letter by Prof Baumbach in Die Beeld (4 February 1983) in which she stressed the need to work hard to preserve Latin, irrespective of its connection with Law, Patrick Ellis, a member of the Secretariat of the SA Law Commission, published a short article in Akroterion in which he gives a brief history of the development of the former Law Reform Committee into the South African Law Commission in 1973. He refers to Section 4(e) of the SA Law Commission Act No. 19 of 1973 in terms of which the Law Commission was given 'the task of recommending means whereby the common law sources would be made more readily available'. The Commission was instrumental in the publication of the following translations and registers: Arntzenius, Institutiones juris Belgici de conditione hominum, translated by the Hon F P Van den Heever (former Judge of Appeal); Brouwer, De jure connubiorum, translated by Proff D B Bosman and P Van Warmelo; Groenewegen, De legibus abrogatis, vols. 1 and 2, translated by Prof Beinart (University of Birmingham); Robert-Joseph Pothier, Traité $d u$ contrat de mandat, translated and edited by Prof A J Kerr (Latin), Prof De Wet and B G Rogers (French); Registers on the Observationes tumultuariae of Van Bykershoek and Pauw, compiled by Prof Van Warmelo. In the process of publication were Groenewegen, De legibus adrogatis, vols. 3 and 4, translated by Prof Beinart and Mrs M Hewett; Neostadius, De pactis antenuptialibus, translated by Proff Bosman and Van Warmelo; Nassau La Leck's register of certain old authorities, edited by Mr SIE van Tonder SC; and Gerlach Scheltinga's commentaries on the 'Inleidings' of Hugo de Groot, edited by Proff G G Visagie and $\mathrm{W}$ de Vos. There was still more work to be done in this field and classicists had a responsibility to 'keep the ship of our legal heritage afloat'. He appealed urgently to anyone who could assist in translating the old authorities from Latin to come forward. ${ }^{41}$

\footnotetext{
39 Saayman to S, 5 June 1984.

40 S to Saayman, 12 June 1984.

41 Ellis 1983. For the full titles and publication details, see Henderson 1995:85-88.
} 


\subsection{School Latin}

The Human Sciences Research Council issued its second report on the position of Latin at South African schools: 'The position of Latin at school: A comparative study between some western countries with special reference to the position at secondary schools in the RSA' ${ }^{42}$ Four further reports were envisaged: 3. 'Extrinsic factors that influence the position of Latin as a school subject in the RSA'; 4. 'The staffing situation as a factor influencing the position of Latin as a school subject in the RSA'; 5. 'Intrinsic factors that influence the position of Latin as a school subject in the RSA'; and 6. 'The position of Latin as a school subject at secondary schools in the RSA: summary and recommendations. ${ }^{43}$

Prof Bruwer published a comprehensive memorandum on the new core syllabus for Latin. She gave a theoretical survey of the problems presented by the existing syllabus (109-13), listed the comments (in English and Afrikaans) of teachers on the syllabi and its examination (from completed questionnaires of the HSRC enquiry on the position of Latin) (113-21); the revision of the curriculum: its premises and reservations (121-23); and the development of the new Latin syllabus (123-30), which entailed:

1. the viability of Latin (123-24);

2. the aims of teaching Latin at secondary level (124-26);

3. which language skills were to be mastered (126-27);

4. the language content: vocabulary, syntax, accidence (127-30);

5. teaching methods (130);

6. working out the details of aims (130); and

7. methods of evaluation (130). ${ }^{44}$

Miss Pat Story, Deputy Director of the University of Cambridge Schools Classics Project, gave a lecture at the University of the Witwatersrand, on 18 August 1983, as guest of the Department of Classics. The large audience of teachers was treated to a stimulating demonstration and informative discussion. Prof Goodyear then spoke on the position of Classics in Great Britain. ${ }^{45}$

42 The first was by P J Maree, 'The justification for the inclusion of Latin in the school curriculum' (Pretoria: HSRC 1983). Cf. Smuts 1984b. Report 6, by B P Weideman, was published a year later. For all the reports, with discussion, see Malan 1988.

43 J O T van Schalkwyk to Henderson, 28 May 1984.

44 Bruwer 1983.

45 Transvaal Regional Branch Annual Report 1983, item 9. 


\subsection{Next conference}

The Secretary informed Prof Chapman that the Executive had accepted his offer of hosting the next conference at the University of Natal, Pietermaritzburg, and suggested to the Executive that Prof Chapman be co-opted on to the Executive for the purpose of organising the conference. The venue was changed from Rhodes University to Natal University in view of the celebration of the 75th anniversary of the founding of the University of Natal. ${ }^{46}$ The conference was to be held from 22 to 25 January 1985. Invitations in English and Afrikaans went out to members to offer papers of a maximum duration of 35 minutes on the main theme or any other. One speaker requested a different time-slot and suggested parallel sessions for the Afrikaans and English papers in consideration of the overseas visitors. ${ }^{47}$ The suggestion was partially accommodated: rather than separate sessions for Afrikaans and English papers, parallel sessions were scheduled on days 3 and 4 (24 and 25 January), with the five Afrikaans papers spread about ( 3 on day 1, 1 on day 2 , and 1 on day 4$).^{48}$

Attempts were still being made to find two experts on modern literary theory. Prof Baumbach would approach three scholars at UCT; ${ }^{49}$ Drs Coulter and Snyman obliged.

\subsection{Regional Branches}

\subsubsection{Eastern Cape}

Although the Eastern Cape Regional Branch had officially ceased to exist, teachers and lecturers continued to meet regularly. On 22 April 1983 a symposium for teachers was held in the 1820 Monument in Grahamstown. An audience of twenty listened to Mr J S Labuschagne, Chief Education Planner in the Department of Education, speak on 'Some considerations fundamental to the planning of the new Latin syllabus'. This was followed by a talk by Prof H Hewitt on the literary background to Pliny's letters and the differences between his and Cicero's letters, and one by Mr J Jackson on some aspects of Ovid's Metamorphoses 10.560-680 and 8.152-235. During the afternoon session, Dr Matier made a strong plea for teachers to become Associate Members of CASA and then informed the meeting of the HSRC report on the position of Latin as a school subject in secondary schools

\footnotetext{
46 S to Henderson, 12 December 1983; Minutes of Executive Meeting, 3 July 1984, item 9.

47 E Schütrumpf to S, 14 August 1984.

48 List of offers received; Provisional Programme; Final Programme.

49 Drs Pakendorff (German), Coulton (English) and Snyman (Afrikaans/Nederlands). S to Henderson, 3 May 1984. There was no success at RAU; Henderson to S, 9 May 1984.
} 
in South Africa. Information was given on visual aids (in particular the colour slides of the Department of Classics at Rhodes) available to teachers and the proposed re-issue of Acta Diurna (1946-1975). Practical problems were next on the agenda: how to build up and teach vocabulary; how to mark unseens and help pupils improve; the allocation of marks in Senior Certificate Latin; and how important was a thorough knowledge of the rules of accidence and syntax in the context of the current trend in examining. ${ }^{50}$

\subsubsection{Natal}

The AGM was held on 12 May 1984. This was followed by a series of activities: a Roman dinner at Pietermaritzburg Girls' High; a production of Euripides' Bacchae by Epworth School, directed and produced by Mr M Lambert; talks to school pupils by Prof Chapman, on the Trojan War and the Olympic Games, and Prof Murgatroyd on Caligula, the Acropolis and peculiar animals in the ancient world; ${ }^{51}$ and a Latin reading competition held in Durban. At the AGM on 8 September 1984 Prof P Murgatroyd was elected as Chairperson and ViceChairperson (Pietermaritzburg) and Dr P Brain as Vice-Chairman (Durban). Prof Murgatroyd gave a talk on Heinrich Schliemann..$^{52}$

A 'Homerathon', a 24-hour non-stop recital of the Iliad, took place on the Durban campus from noon on Friday, 18 May to just before noon on Saturday, 19 May 1984. The relay of readers, robed and holding a staff, read about 400 lines each from Richmond Lattimore's translation, with the odd 100 lines of Greek thrown in. Coffee and wine kept proceedings moving. Participants were drawn from Classics, English, Speech and Drama, and Medicine and the changing audience was a mixture of Homeric enthusiasts, students and curious bystanders..$^{53}$

\subsubsection{Transvaal}

The Committee for 1983 consisted of Mr J J A De Villiers (C), Dr M J Mans (VC), Mr G J Mader (ST), and the following represented the universities and schools: Dr A G P Van der Walt (Potchefstroom), Mr A Basson (RAU), Mr T Rapke (Witwatersrand), Mr C M Jooste (University of the North); Miss H Möller, Miss D Visser (Afrikaans medium schools), Mr F Barnicoat, Mrs S Nell and Mrs S Harris (English medium schools), and Mrs F Lonstein (Private schools).

\footnotetext{
50 Matier 1983.

51 Murgatroyd 1984a.

52 Murgatroyd 1984b.

53 See Whitaker 1984.
} 
A Teachers' Conference was held on Saturday, 19 March 1983 at Helpmekaar Girls' High. The attendance was disappointing due to other school activities. Mrs M Schoeman gave a talk on the appreciation and interpretation of prescribed works, with the myth of Daedalus and Icarus in Ovid as an example. Attendance was much better when, on 21 May 1983, the Annual reading, poster (on a fable of Aesop or Phaedrus) and model (the Colosseum or Circus Maximus) competitions took place at SAHETI School. After the judging and prize-giving, Mr Mader showed some films with a classical background.

At the AGM of the Transvaal Regional Branch held at RAU on 24 September 1983, Mr P J Coetzee gave a talk on 'Argument and style in Cicero's Philippica', and Mr A Devine (University of the Transkei) one on 'The self-image of Alexander the Great'. Dr Mans delivered a laudatio in honour of Dr D M Kriel who was leaving on 30 September 1983 to take up the position of Cultural Attaché in Rome. ${ }^{54}$ There were only two changes to the previous Committee: $\mathrm{Mr}$ Basson replaced Mr Mader as Secretary-Treasurer and Dr Saayman replaced Mr C M Jooste as representative of the University of the North. ${ }^{55}$

At a Teachers' Conference, held at Helpmekaar Girls' High School on 17 March 1984, Prof D B Saddington gave a talk on Petronius' Cena Trimalchionis, and Prof J Scholtemeijer one on the life and career of Hannibal. Mrs Harris chaired a discussion on the Classical Civilisation topics for Stds 6, 7 and 8. On 19 May 1984 the Annual Competitions took place at SAHETI. While the reading competition was in progress, Dr Mans gave an illustrated talk on the Circus Maximus and Mr Mader again screened films with a classical content. For the poster and model competitions, both on the themes of Hannibal's career, Pyramus and Thisbe and Phaeton, there were 80 and 60 entries respectively.

The AGM was held at the University of Pretoria on 22 September 1984, where Prof F Goodyear gave a lecture on 'Fifty years of classical scholarship (1933-1983)' and Prof J P Louw one on 'Woorde en betekenisse: 'n semantiese probleem'. The Committee for 1984 would consist of Dr Mans (C), Mr Rapke (VC) and Mr Basson (S-T). The representatives of the universities and schools were to remain the same, except that Dr F Bredenkamp was to represent Unisa. ${ }^{56}$

There were other activities related to the Classics. On 30 July 1983 the Transvaal Teachers' Association held a conference at the Johannesburg College of Education, at which Mrs Harris spoke about teaching Latin grammar at the Junior Secondary Phase and Mr De Villiers discussed the trends in the content of syllabuses, and in particular the Classical Culture component. On 30 August 1983

\footnotetext{
54 See Mans 1984.

55 Transvaal Regional Branch Annual Report 1983.

56 Transvaal Regional Branch Annual Report 1984.
} 
a Latin evening was held at Greenside High School for Std 5 pupils and their parents, aimed at encouraging pupils to select Latin as an optional subject in Std 6 . On 12 May 1984 a Transvaal Teachers' Association conference was held at the Johannesburg College of Education, where Prof Goodyear spoke on 'The characters of Hannibal and Scipio', Mr J Alswang (Inspector of Schools) on the new Latin syllabus, and Mr De Villiers on the pronunciation of Latin. Sir Ronald Syme gave a lecture on 'Caesar: drama, legend, history' at the University of the Witwatersrand on 16 August 1984, and Prof Saddington gave a talk on 'The Romans in Africa: Exploration and urbanisation' to the Wits Medical School. ${ }^{57}$ Prof Scholtemeijer's Afrikaans translation of Plautus' Miles gloriosus (Brigadier $B e k$ ) was produced at Die Masker at the University of Pretoria on 3-10 May 1984..$^{58}$ This followed the production of the Menaichmi (Gebodder met die broeders) on 13-22 September $1979 . .^{59}$

\subsubsection{Western Cape}

The second day-long workshop for Latin teachers was held at the Teachers' Centre, Mowbray, on 2 February $1983 .{ }^{60}$ About 40 university and school teachers, as well as student-teachers, attended. The first session was devoted to a discussion of the new core syllabus. The first speaker, Mr Labuschagne, Head Education Planner for Humanities of the Cape Education Department, reported on the proposed new syllabus for Latin, the support and opposition encountered in the phase where various interested parties were given the opportunity to offer comments, and the problem of including translation into Latin and comprehension testing. The present form of the syllabus was a result of compromise, offering enough alternatives for each examining body. The syllabus aimed at developing awareness in pupils and trustworthy professional integrity and personal predilections of teachers. The next speaker, Prof F Smuts, talked about Pliny as revealed in his letters, a component of the Cape Senior Certificate examinations for 1983 and 1984. With the aid of a hand-out outlining the various aspects as they appeared in the letters, he characterised Pliny as an author who did his duty to emperor and society to make the Empire 'work'. ${ }^{61}$ This was followed by video-

57 Transvaal Regional Branch Annual Report 1984.

58 Transvaal Regional Branch Annual Report 1984; Mans to Basson, 2 April 1984. In the event, the play ran until 12 May 1984.

59 The two plays, together with two others, Die spookhuis (Mostellaria), performed on 22 February-1 March 1986, and Potparanoia (Aulularia), performed on 18-25 May 1991, were published posthumously as Plautus praat vlot Afrikaans (Pretoria: Cordis Trust Publikasies, 2012). For a review, see Henderson 2013b.

${ }_{60}$ See the report by Claassen 1983.

${ }^{61}$ For the hand-out, see Smuts 1983. 
recordings of teachers giving lessons to Std 9 classes: Miss S Armstrong of Westerford tackled an epigram of Martial, had pupils presenting different verse translations and a 'TV news programme' on Ovid's Daedalus and Icarus; and Mr K Richardson of Plumstead High displayed his skills in a lesson on translating Vergil. After tea Mrs B Gibson of Groote Schuur High led a discussion of problems in teaching set work. Questions such as the use of a fair copy, the testing of grammar, and the difficulty of teaching literature within the bounds of the available time. Mrs B van Zyl Smit then spoke on another set topic for 1983/84, love in Ovid's Metamorphoses. ${ }^{2}$ The showing of the Encyclopaedia Britannica film Vita in Roma Antiqua, with Latin narration, initiated discussion on the use of audio-visual aids as a means of canvassing among Std 5 pupils. Mrs J-M Claassen quoted facts and figures to show that, where information had been disseminated among Std 5 pupils, there had been an increase in Std 6 enrolments. She encouraged teachers to believe in the ultimate educational value of Latin, which was on a par with maths or biology in terms of general education. After briefly touching on a 'Memorandum on visits to primary schools' compiled for colleagues at other universities, she gave a sample lesson using a map of the Mediterranean area. After lunch, Mrs M Mezzabotta gave a talk with slides on the Colosseum, in which she emphasised its social importance and function, adding that Classical studies should carry an X-rating (not for children under 21). She sounded a more serious note in pointing out the decimation of certain species of wild animal by hunters capturing animals in Africa and the wholesale slaughter of humans in the gladiatorial combats.

A third workshop for Latin teachers took place on 8 February $1984 .{ }^{63}$ This time there were 55 persons present: teachers from schools in the Western Cape (from as far as Kimberley and George), university lecturers, invited guests, and representatives of three examining bodies. A registration fee of R50 was levied to cover the costs of two lengthy handouts: 'Munera magistris', a collection of articles on education from Newsletter and Akroterion; and a collection of internal examination papers of various levels offered by teachers. Prof J E van der Westhuizen (English Department, UCT) opened the proceedings with an address in which he encouraged Latin teachers not to become despondent, reminding them that they were imparting a valuable and enriching aid to South African youth. ${ }^{64} \mathrm{Mr}$ Labuschagne, as representative of the committee for the revision of the core syllabus, introduced a group discussion on the possibility of a Standard Grade examination or course in Latin, by saying that in principle such a project

\footnotetext{
62 Van Zyl Smit 1983.

63 Claassen 1984; Mezzabotta 1984:85

${ }^{64}$ See Van der Westhuizen 1984.
} 
should be accommodated, but that the thinking among educational authorities was that emphasis should be given to what Latin offered the average pupil (vocabulary enrichment, a feel for grammatical usage, an introduction to classical thought). Various views were expressed and the final feeling was that Standard Grade Latin could widen the scope of the outreach of Latin and was a better option than lowering the standard of the subject. The second session on 'Standard Six as a year of exploration' was introduced by Mr C Clement, Inspector of Schools. He gave a lively display of how a teacher could be her/his own audio-visual aid to make the subject more interesting, informative, educational and attractive and gave the following advice: the attention span of a Std 6 pupil was one minute; a pupil wants to speak Latin on day one; a pupil likes to have a Latin nickname; Std 6 pupils need a chronological framework and awareness; and Std 6 pupils love useless information. During the group discussion several points were raised and comments made. The third session consisted of a 'Think tank', chaired by Mrs G Solomon (UCT). Four speakers gave short talks: Miss Zaaiman (D F Malan High School) on what Latin could offer the 'gifted pupil'; Mr D Fitzgerald (St Joseph's College) on the successful simultaneous introduction of Latin at the Std 4, 5 and 6 levels the year before; Mrs S Hey (Westerford) on different kinds of group-work that were feasible in the classroom; and Mrs Meinert (Model Library of the Cape Education Department) on the facilities offered to CED schools.

A Latin Reading competition took place on 25 April 1984 at Settlers' High School, and on 5 September a quiz, attended by 150 people, was held at Groote Schuur High School. On the same evening, the results of the Art Competition for Standards 6-8, which replaced the annual Ludi Romani, were announced. On 4 May, Mr G Hoberman gave an illustrated talk on Greek and Roman coins to an audience of 50 at the University of Cape Town. This was also the venue of a meeting of the lecturers of the three southern universities on 16 August at which Ms Fiona Cawsey (Bedford College, London) gave a talk on 'Elegiac elements in Vergil's Eclogues'. At an International Conference on Education for the Gifted, held at Stellenbosch on 25-29 June 1984, Prof B van Stekelenburg read a paper on 'Classics for the gifted', which Mrs Claassen supplemented with 'Some practical suggestions'. ${ }^{65}$

${ }_{65}$ Mezzabotta 1984. See Van Stekelenburg 1985a. 
The First Business Meeting took place on Tuesday, 22 January 1985, from 08:30 to 11:00. Forty-five delegates were present; twenty-five had sent apologies for absence. The Acting Chairperson, Prof De Wet, announced that the Chairperson, Prof Baumbach, had been delayed in Europe by bad weather. He then expressed dismay at the number of withdrawals of papers offered, which had necessitated changes to the programme. He appealed to members who offered to present papers to regard this commitment as an obligation. Under 'Personalia' delegates observed a moment of silence in memory of Prof Suretha Bruwer. Professors U Vogel and Whitaker were congratulated on the publication of their books. After the approval of the minutes of the previous conference, matters arising from the minutes were dealt with. The appointment of Prof Matier as permanent CASA delegate on FIEC was confirmed. ${ }^{66}$ The decision of the Executive against the appointment of a PRO and in favour of this function being the responsibility of the local branches was approved ${ }^{67}$ Also to be devolved on the regional branches was the task of tracing all teachers of Latin and compiling a list of available Latin teachers. ${ }^{68}$ The meeting voted against Prof E L de Kock's proposal to appoint speakers to introduce discussion on each paper. ${ }^{69}$ Opinions were divided on the issue of requiring speakers to make copies of their papers available before delivery. For practical reasons the Executive had proposed to reject the requirement of either a copy or a summary of the paper, suggesting only an abstract for acceptance of the paper. Prof P J Conradie proposed that at least a bibliography ought to be provided; and Prof Vogel proposed that abstracts of all the papers be provided at the beginning of the conference. This latter proposal was carried. ${ }^{70}$ It was decided to hold the next Colloquium in 1986 at the University of the Orange Free State. ${ }^{71}$

The various reports were then tabled. Prof Baumbach flew in from Johannesburg to Oribi Airport just in time to deliver her report. She expressed her condolences on the death of Prof Bruwer and mentioned the absence of Prof Kriel who was in Rome. She reported on the activities of the Western Cape Regional Branch and thanked Prof Henderson for organising the Colloquium in 1984. She welcomed the two guest speakers and thanked the two outside experts, Drs Coulton

66 Agenda; Minutes of First Business Meeting, 6.1.

${ }_{67}$ Agenda; Minutes of First Business Meeting, 6.2.

68 Agenda; Minutes of First Business Meeting, 6.3, 6.

69 Agenda; Minutes of First Business Meeting, 6.4.

70 Agenda; Minutes of First Business Meeting, 6.5.

71 Agenda; Minutes of First Business Meeting, 6.7. 
and Snyman. She reported that the Executive had kept in contact by letter and telephone and personal meetings when possible. She ended by thanking the members of the Executive. ${ }^{72}$

Prof Whitaker presented the Treasurer's report, which was accepted with thanks. The paid-up membership of the Association as at the end of 1983 stood at 187 Full Members, 76 Associate Members, 25 Student Members, 7 Life Members and 3 Honorary Members. The Saambou paid-up shares were redeemed and a fixed deposit of R2 500 opened, adding to the R1 400 already invested with the Permanent Building Society. Combined with the high interest rates this had enabled CASA to double its income during the past two years. The balance sheet showed net current assets of R4 176 (20/12/1982) and R6 722 (31/12/1984). Grants of R1 500 and R750 for Acta Classica and Akroterion respectively had been budgeted for 1985/6. An amount of R500, approved by Executive, had been contributed to the costs of bringing Dr Easterling to the conference. Administrative costs (stationery, postage, printing) had mostly been met by the Department of Classics at Natal University, Durban, which resulted in only R75.70 debited to the Association's account. The previous Treasurer's innovation of producing sets of machine-printed address-labels on computer was maintained, and it was recommended that this process should be kept. It was also recommended that the annual grant to the Regional Branches be doubled from R1 per member per annum to R2, and that the subscription for Full members be increased to R18. The report and recommendations were approved. ${ }^{73}$

Prof C P T Naudé tabled the report of the Editorial Committee of Acta Classica. The membership of the Committee had changed: Prof Kriel resigned in 1983 to take up a position as Cultural Attaché in Rome and Prof Saddington was co-opted in his place; Mr P Hasse resigned as Editorial Secretary in 1983, but continued to compile the list of exchange periodicals in Acta Classica; and Prof $\mathrm{H}$ Gonin indicated that he wished to retire as Managing Editor at the end of 1983, but would continue until a replacement was appointed. The financial statement reflected contributions of R1 350 and R1 140 by the Department of National Education as subsidies in 1982/3 and 1983/4; two further grants of R925 and R1 060 were paid for $1983 / 4$ and 1984/5; and another grant of R975 for $1985 / 6$ was forthcoming. Income from subscriptions amounted to only R717, but universities contributed R902 in 1983 and R1 005 in $1984 .^{74}$ The cost to typeset and print Vol. XXVI (1983) was R2 066.47 and R1 245.50 (= R3 311.97), and to

72 Agenda; Minutes of First Business Meeting, 7.1.

73 Agenda; Treasurer's Report; Minutes of First Business Meeting, 7.2.

74 1983: Witwatersrand R432, UCT 120, Unisa R350; 1984: Witwatersrand R300, UCT R120, Unisa R185, Pretoria R400. 
typeset Vol. XXVII (1984) R3 328.82 (the account for printing to be settled in the new year). The increase in the cost of the typesetting was due to extra pages (115 to 153), an agreed increase of the cost per page from R15.54 to R17.40, and the excessive proof-correcting caused by 'the deplorable state of some manuscripts', which added R364 to the account. The expected cost of Vols XXVIII (1985) and XXIX (1986) was at least R5 000 per volume. The annual expected subsidy was R1 000 (Department of National Education), R1 300 (CASA), R1 250 (Universities, various) and about R1 000 from subscriptions, leaving a shortfall of about R500. The report ended with a request for the appointment of a successor to Prof Gonin and a possible increase in the subsidy from CASA, and a strong directive to authors to submit manuscripts that heeded the editorial guidelines and had a regard for correct language and clear style. The meeting postponed the appointment of a successor to Prof Gonin to the Second Business Meeting. After some discussion it was decided to grant the journal R1 500 for 1985 and R1 750 for 1986. Prof Scholtemeijer reported that some 180 subscribers in Europe and the USA had not received Acta Classica since Balkema had not provided the list of these subscribers in time. The Editorial Committee was requested to do what was necessary to solve the problem. The matters of the condition of submitted manuscripts and the length of Acta Classica were referred to the next Editorial Committee. ${ }^{75}$

Prof Conradie presented the report on Akroterion on behalf of Prof Smuts. The September and December 1983 issues had been combined into a volume in honour of Prof Smuts, which had increased the number of pages to $171 .{ }^{76}$ Rising costs were a cause of concern. Total income for 1983-84 amounted to R3 249.61 and expenses incurred were R3 182.75, leaving a credit balance of R66.86; additional funding was requested from the Association. It was agreed to increase the grant to R750 for 1985 and R900 for 1986. The Editorial Board of Akroterion proposed to publish the papers presented at the Colloquium in a special volume. Fifteen speakers had each donated R10 and another R150 had been donated by the Tria Saecula fund, but a further R500 was needed for publication. Prof Goodyear, seconded by Prof De Kock, proposed that only worthwhile papers should be published and then in regular issues of Akroterion. After discussion the meeting voted 19 to 14 against the publication of a special issue. ${ }^{77}$ A suggestion by Prof Whitaker, supported by Prof Henderson, that Colloquium papers should in future be printed in a Colloquium manual, was approved. ${ }^{78}$

\footnotetext{
75 Agenda; Acta Classica Report; Minutes of First Business Meeting, 7.3.

76 For tributes, see Baumbach 1983 and De Vries 1983.

77 See Smuts 1985 b.

78 Agenda; Akroterion Report; Minutes of First Business Meeting, 7.4.
} 
Prof Henderson informed the meeting about the HSRC reports on the position of Latin at schools, and mentioned that the late Prof Bruwer had to be replaced as CASA representative; this would be done at the Second Businees Meeting. ${ }^{79}$ Prof De Wet, Chairperson of the Subcommittee for Classical Culture at Schools, reported that it had been decided to await the effects of the new syllabus, which apparently included a 30\% component of Classical Civilisation in the early years, diminishing to $20 \%$ by matric. ${ }^{80}$

Notice of the following motions affecting the constitution was then given:

1. that clause 4(a) on student members registering for three years in advance be deleted;

2. that the annual grant to the regional branches be doubled to R2 per person;

3. that a non-refundable conference fee, to be determined by the Executive, be levied for attendance at CASA conferences and colloquia;

4. that the final sentence of clause 9 (on the election of liaison officers) be deleted;

5. that subscription fees for Full Members be increased to R20; and

6. that a special category of membership be created under Section 3 for persons interested in classical studies but not necessarily possessing formal qualifications. ${ }^{81}$

The proposed venue (Stellenbosch) and theme of the next conference in 1987 were to be finalised at the Second Business Meeting. ${ }^{82}$ Under 'General', Prof Whitaker informed the meeting that about R560 was still needed to cover the cost of Mrs Easterling's airfare, part of which had been paid for by Cambridge University, and R400 by the University of the Orange Free State. ${ }^{83}$

The Second Business Meeting was held on Friday, 25 January 1985, from 10:45 to 12:30, and was attended by 47 delegates. All the motions proposed at the First Business Meeting were carried unanimously; the wording of 6 . was finalised to read: 'Persons of standing having an interest in classical studies but not necessarily possessing formal qualifications in the subject, may be proposed by two members and the proposal must be considered by the Executive. They will pay the membership fee applicable to members' ${ }^{84}$ A motion that an overseas guest

\footnotetext{
79 Agenda; Minutes of First Business Meeting, 7.5.

${ }^{80}$ Agenda; Minutes of First Business Meeting, 7.6.

${ }^{81}$ Agenda; Minutes of First Business Meeting, 7.8.

82 Agenda; Minutes of First Business Meeting, 9, 10.

83 Minutes of First Business Meeting, 11.

${ }^{84}$ Agenda; Minutes of Second Business Meeting, 2.
} 
speaker be invited to future conferences and that, if necessary, CASA should fund the visit but make every effort to obtain funding elsewhere, was carried unanimously after much debate..$^{85}$ The theme of the next Colloquium (1986) was to be 'The teaching of ancient history at university level' ${ }^{86}$ The next conference was to be held at the University of Stellenbosch, with the theme 'Greek and Latin lyric poetry' gaining the majority vote. ${ }^{87}$ The following were elected: Prof Vogel as Managing Editor of Acta Classica; Dr D B Lombard as Treasurer of Acta Classica when Prof Naudé retired; Dr Mans as representative on the HSRC Committee; and Mr L van Ryneveld as Colloquium organiser. Members of the new Executive were to be: Prof De Wet (C), Prof Baumbach (VC), Prof Matier (S) and Dr J Cilliers (T) ${ }^{88}$ The Secretary read a letter from Dr B Lewis of the University of Port Elizabeth giving an account of the activities in Port Elizabeth during 1984. It was proposed that the new Executive should try to resuscitate the Eastern Cape Branch. Secretaries of the Regional Branches were requested to submit their reports to the Secretary and Treasurer as soon as possible in order to qualify for funding. ${ }^{89}$ Votes of thanks were proposed to the Principal of the University of Natal for the reception, hospitality and facilities of the University Staff Club; to Prof Gonin for his untiring labours as Managing Editor of Acta Classica since 1967; to Prof Chapman and his colleagues for their organisation and hospitality; to the outgoing Executive Committee; to the 75th Anniversary Committee of the University of Natal for their generous funding of the visit of Prof David Campbell; and to Prof Baumbach for her contribution as Chairperson. ${ }^{90}$ Several matters were raised under 'General'. It was announced that a number of visitors were expected in 1985: Dr Michael Winterbottom (16 March-25 April), Sir Ronald Syme (July), Prof Harry Jocelyn (late July), Prof Bruce Metzger (August/September), Prof Werner Eck (September) and Prof John Luce (September/October). ${ }^{91}$ Prof Baumbach reported that letters had been sent to the Chief Justice and the Minister of Education in connection with the requirement of Latin for lawyers. ${ }^{92}$ The Editorial Committee was requested to consider dedicating the next volume of Acta Classica to Prof Bruwer. ${ }^{93}$ Proff Conradie and Vogel invited contributions to Akroterion and

Agenda; Minutes of Second Business Meeting, 3.

Agenda; Minutes of Second Business Meeting, 4.

Agenda; Minutes of Second Business Meeting, 5.

Agenda; Minutes of Second Business Meeting, 6.

Agenda; Minutes of Second Business Meeting, 7.

Agenda; Minutes of Second Business Meeting, 8.

Agenda; Minutes of Second Business Meeting, 9.1.

Agenda; Minutes of Second Business Meeting, 9.2.

Agenda; Minutes of Second Business Meeting, 9.3. 
Acta Classica respectively. ${ }^{94}$ Finally, Prof Henderson pointed out that Acta Classica was now published by the Association itself and that Clause 15 of the constitution would have to be amended accordingly for approval at the First Business Meeting during the next conference. ${ }^{95}$

Twenty-nine papers were delivered, including papers by the guest speakers, Dr Easterling, who spoke on 'The world of tragedy', and Prof Campbell, whose topic was 'Horace and the Greek monodists'. ${ }^{96}$ Prof Baumbach's presidential address dealt with 'Shakespeare and the Classics'. ${ }^{97}$

\section{Conclusion}

It seems fitting in this report to add some concluding remarks regarding issues that arise concerning the state of CASA and the Classics for the period until 1985.

The first issue is the strength of CASA in the period 1981 to January, 1985, and the membership and numbers for each province. The minutes of the first three 'foundation' conferences record the number of delegates as 17 (1956), 23 (1957) and 22 (1959). ${ }^{98}$ The membership figures for the period 1961-1981 show a steady increase: 130 (1961), ${ }^{99} 197$ (1963), ${ }^{100} 200$ (1966), ${ }^{101} 250$ (1969 and 1973), ${ }^{102} 193$ (1975), ${ }^{103} 218(1977),{ }^{104} 257(1979){ }^{105}$ and $340(1981) .{ }^{106}$ From this peak a decline set in, from 314 in January $1983^{107}$ to 298 in January 1985 (see above, 2.1). The membership numbers of the regional branches were never tabled at the biennial conferences; they were primarily used by the Treasurer for the proportional distribution of grants to the branches. A search of the archival documents (mainly subscription lists) produced only partial information; there were no membership lists giving regional affiliations for the period February 1983 to January 1985,

\footnotetext{
94 Agenda; Minutes of Second Business Meeting, 9.4, 5.

95 Agenda; Minutes of Second Business Meeting, 9.6.

$96 \quad$ See Campbell 1985.

97 See Baumbach 1985a.

98 Cf. Henderson 2004:90, 92, 100.

99 Cf. Henderson 2005:109.

100 Cf. Henderson 2005:115.

101 Cf. Henderson 2006:135.

102 Cf. Henderson 2006:145; 2007:106.

103 Cf. Henderson 2008:81.

104 Cf. Henderson 2008:88.

105 Cf. Henderson 2010:88.

106 Cf. Henderson 2010:107-8.

107 Cf. Henderson 2014:134, where 'full members' presumably included associate members.
} 
evidently a result of computerisation. ${ }^{108}$ The following statistics are therefore incomplete and offered as a general survey; figures were also subject to fluctuations during the course of a year due to new membership, late payment of subscriptions, relocation, cancellation, death and - in the case of student members - graduation. Hence the difference in the figures for 1983 and 1985 in the following tables.

$[\mathrm{EC}=$ Eastern Cape; NTL $=$ Natal; OFS $=$ Orange Free State; TVL $=$ Transvaal; $\mathrm{WC}=$ Western Cape; $\mathrm{ADD}=$ untraceable, emigrated, South West Africa, USA, Zimbabwe]:

1983

$\begin{array}{llllllll}\text { CATEGORY } & \text { EC } & \text { NTL } & \text { OFS } & \text { TVL } & \text { WC } & \text { ADD } & \text { TOT } \\ \text { Honorary } & 0 & 1 & 0 & 3 & 1 & 0 & =5 \\ \text { Life } & 0 & 0 & 0 & 2 & 1 & 4 & =7 \\ \text { Full } & 14 & 21 & 17 & 70 & 39 & 10 & =171 \\ \text { Associate } & 6 & 2 & 2 & 12 & 28 & 22 & =72 \\ \text { Student } & 0 & 2 & 1 & 4 & 19 & 0 & =26 \\ \text { Total } & 20 & 26 & 20 & 91 & 88 & 36 & =281 \\ \text { Percentage } & 7,1 & 9,3 & 7,1 & 32,4 & 31,3 & 12,8 & =100\end{array}$

1984

$\begin{array}{llllllll}\text { CATEGORY EC NTL OFS TVL WC } & \text { ADD } & \text { TOT }\end{array}$

$\begin{array}{llllllll}\text { Honorary } & 0 & 1 & 0 & 3 & 1 & 0 & =5 \\ \text { Life } & 0 & 0 & 0 & 2 & 1 & 4 & =7 \\ \text { Full } & 18 & 22 & 17 & 75 & 44 & 12 & =188 \\ \text { Associate } & 5 & 41 & 2 & 9 & 34 & 21 & =112 \\ \text { Student } & 0 & 3 & 1 & 5 & 41 & 0 & =50 \\ \text { Total } & 23 & 67 & 20 & 94 & 121 & 37 & =362 \\ \text { Percentage } & 6,4 & 18,5 & 5,5 & 26,0 & 33,4 & 10,2 & =100\end{array}$

108 I wish to thank Johan Cilliers, Jo-Marie Claassen, Koos Kritzinger, Richard Whitaker and Christoff Zietsman for their help in gathering further information. 


\section{5}

$\begin{array}{llllllll}\text { CATEGORY } & \text { EC } & \text { NTL } & \text { OFS } & \text { TVL } & \text { WC } & \text { ADD } & \text { TOT } \\ \text { Honorary } & 0 & 1 & 0 & 3 & 1 & 0 & =5 \\ \text { Life } & 0 & 0 & 0 & 2 & 1 & 4 & =7 \\ \text { Full } & 14 & 22 & 15 & 67 & 46 & 22 & =183 \\ \text { Associate } & 4 & 38 & 2 & 9 & 26 & 21 & =103 \\ \text { Student } & 0 & 1 & 0 & 5 & 17 & 2 & =25 \\ \text { Total } & 18 & 62 & 17 & 86 & 91 & 49 & =323 \\ \text { Percentage } & 5,6 & 19,2 & 5,3 & 26,6 & 28,1 & 15,2 & =100\end{array}$

The second issue relates to the number of universities that offered Classics. As a matter of fact, all the universities at the time had Departments of Classics, or Greek or Latin, with permanent chairs and at least one lecturer, and in many cases a senior lecturer or two. ${ }^{109}$

The third issue regards the number of classical scholars, that is university teachers of Classics. No such details were tabled at conferences, since not all CASA members were classicists, and not all classicists were members of CASA. However, the membership lists for 1983, 1984 and 1985 included 101 classical scholars for 1983 and 1984, and 96 for 1985. The broader history of Classics at South African universities, based on an examination of the personnel records of the universities and the regular news items published in Akroterion, would be a worthwhile research project.

Fourthly is the question of how many post-graduate students there were during this period. Departments did not report such matters at conferences and this information is therefore not documented in the archives. However, I published an article which records the figures for post-graduate students for the years 1980-1985 (keeping in mind, of course, that students took these courses over more than one year): $:^{110}$

109 The universities were Cape Town, Western-Cape, Stellenbosch, Transkei, Rhodes (Grahamstown), Port Elizabeth, Fort Hare, Natal (Durban and Pietermaritzburg), Durban-Westville, Zululand, North, Free State, Potchefstroom, Pretoria, Unisa, Witwateresrand and Rand Afrikaans (Johannesburg).

110 Henderson 1986b. The undergraduate enrolments are also given. 
Honours

Greek Latin Classics $\begin{gathered}\text { Classical } \\ \text { civilisation }\end{gathered}$ Total

$\begin{array}{llllll}1980 & 18 & 16 & 2 & 8 & 44 \\ 1981 & 22 & 17 & 2 & 6 & 47 \\ 1982 & 17 & 14 & 0 & 2 & 33 \\ 1983 & 20 & 14 & 2 & 2 & 38 \\ 1984 & 20 & 16 & 0 & 1 & 37 \\ 1985 & 16 & 15 & 2 & 2 & 35\end{array}$

Masters

Greek Latin Classics $\begin{gathered}\text { Classical } \\ \text { civilisation }\end{gathered}$ Total

$\begin{array}{llllll}1980 & 17 & 15 & 3 & - & 35 \\ 1981 & 11 & 10 & 1 & - & 22 \\ 1982 & 12 & 15 & 3 & - & 30 \\ 1983 & 13 & 14 & 8 & - & 35 \\ 1984 & 15 & 12 & 9 & - & 36 \\ 1985 & 13 & 11 & 5 & - & 29\end{array}$

\section{Doctorate}

Greek Latin Classics $\begin{gathered}\text { Classical } \\ \text { civilisation }\end{gathered}$ Total

$\begin{array}{ccccc}1980 & 8 & 8 & 3 & 19 \\ 1981 & 11 & 7 & 3 & 21 \\ 1982 & 12 & 13 & 3 & 28 \\ 1983 & 11 & 9 & 3 & 23 \\ 1984 & 10 & 13 & 2 & 25 \\ 1985 & 10 & 10 & 4 & 24\end{array}$


Finally, Members of the Association were congratulated at conferences on books published in the previous two years. Articles were not mentioned. This was before the system of granting subsidies placed pressure on academics to publish articles. Many professors and senior lecturers rarely published more than an article per year, and concentrated mostly on teaching and research. And yet, apart from publishing articles in international journals, local Classicists have published articles in the two official journals of the Association, Acta Classica and Akroterion (formerly Newsletter), every year for more than 50 years. ${ }^{111}$ It is true, however, that due to the dwindling numbers of permanent classicists at South African universities, fewer articles have been forthcoming in recent years.

Although the focus of this article is on the period 1983-1985, it is at once enlightening and disconcerting to cast a glance a decade into the future. In a survey of the years 1994-1995, Anne Mackay presented a table with the following statistics: ${ }^{112}$

1994: Professors: Potchefstroom 3, RAU 3, Rhodes 1, Cape Town 1, Free State 1, (Natal) 2, Unisa 2, Pretoria 4, Stellenbosch 2, Western-Cape 1 (Total 20). Associate Professors: Rhodes 1, Cape Town 1, Natal 1, Unisa 1, Stellenbosch 1, Wits 1 (Total 6).

Senior Lecturers: Potchefstroom 2, RAU 3, Rhodes 1, Cape Town 2, Free State 2, Natal 5, Unisa 2, Pretoria 2, Stellenbosch 3, Western-Cape 2, Wits 2 (Total 26).

Lecturers: Potchefstroom 2, RAU 1, Cape Town 2, Free State 1, Natal 3, Unisa 7, Pretoria 4, Stellenbosch 3, Western-Cape 2, Wits 1 (Total 26).

Junior Lecturers: Potchefstroom 1, Cape Town 2, Unisa 3, Wits 1 (Total 7).

1995: Professors: RAU 2, Cape Town 1, Free State 1, Natal 1, Unisa 1, Pretoria 3, Stellenbosch 1 (Total 10).

Associate Professors: RAU 1, Rhodes 1, Cape Town 2, Natal 2, Unisa 1, Pretoria 1, Stellenbosch 1, Wits 1 (Total 10).

Senior Lecturers: Potchefstroom 1, RAU 1, Rhodes 1, Cape Town 2, Natal 4, Unisa 1, Pretoria 2, Stellenbosch 2, Western-Cape 1, Wits 1 (Total 16).

Lecturers: Potchefstroom 1, Cape Town 2, Natal 1, Unisa 6, Pretoria 2, Stellenbosch 2, Western-Cape 1, Wits 1 (Total 16).

Junior Lecturers: Cape Town 2, Unisa 1 (Total 2).

111 See Henderson 1986a and 1995.

112 Mackay 1999:83, Table I. She also presents student numbers in Table I (82). 
The drop from a total of 85 to 54 university teachers of Classics in one year was directly linked to the abolition of Latin as a requirement for the LLB degree. ${ }^{113}$ However, the story of the years from 1985 onwards is for someone else to tell.

\section{BIBLIOGRAPHY}

Baumbach, L 1983. Prof Frans Smuts: 'n Huldeblyk. Akroterion 28.3/4:61-62.

— 1985a. Shakespeare and the Classics. AClass 28:77-86.

1985b. The tools of our literary studies - the dictionaries. Akroterion 30.4:93-96.

Bruwer, S 1983. 'n Nuwe kernsillabus vir Latyn. Akroterion 28.3/4:109-130.

Campbell, D A 1985. Horace and Anacreon. AClass 28:35-38.

Claassen, J-M 1983. Latin teachers' workshop - Indiensopleidingseminaar vir Latynonderwysers. Akroterion 28.1/2:27-30.

— 1984. Latin teachers' workshop — Indiensopledingseminaar. Akroterion 29.1:25-29.

Conradie, P J 1985. Griekse letterkunde vir Teologie-studente, met spesiale verwysing na die Griekse tragedie. Akroterion 30.4:88-92.

De Vries, S F 1983. 'Akroterion' alias 'Newsletter': The early days. Akroterion 28.3/4:63-66.

Ellis, P 1983. The South African Law Commission and our legal heritage. Akroterion 28.1/2:58-59.

Hasse, P 1983. Publications received in exchange for Acta Classica. AClass 26:109-115.

— 1984. Publications received in exchange for Acta Classica. AClass 27:145151.

— 1985. Publications received in exchange for Acta Classica. AClass 28:107113.

Henderson, W J 1986a. Bibliotheca Classica Austro-Africana. Institute for AfroHellenic Studies. Johannesburg.

1986b. Classical statistics. Akroterion 31.1:2-12.

— 1995. Bibliography of Greek and Latin Studies in South Africa 1985-1994. Johannesburg.

2004. The Classical Association of South Africa: April 1956-January 1961. Akroterion 49:89-109.

113 Mackay 1999:80. The Classics Departments were closed at the Universities of Zululand (1992), Durban-Westville, Fort Hare, Transkei and Port Elizabeth (all in 1998), although at the first four NT Greek continued to be taught for a while in the Theology Departments; Mackay 1999:80 n. 3. 
Henderson, W J 2005. The Classical Association of South Africa: February 1961July 1966. Akroterion 50:109-123.

2006. The Classical Association of South Africa: July 1966-January 1971. Akroterion 51:135-156.

_ 2007. The Classical Association of South Africa: January 1971 - January 1975. Akroterion 52:99-114.

2008. The Classical Association of South Africa: January 1975 - January 1979. Akroterion 53:99-114.

2010. The Classical Association of South Africa: February 1979 - January 1981. Akroterion 55:87-115.

2013a. The Classical Association of South Africa, 1908 - 1956. Akroterion 58:123-150.

2013b. Review of Jan Scholtemeijer, Plautus praat vlot Afrikaans. Vier komedies van Titus Maccius Plautus in Afrikaans vertaal (Pretoria 2012). AClass 56 (2013) 222-225.

2014. The Classical Association of South Africa, February 1981 - January 1983. Akroterion 59:123-140.

Landman, C 1986. Die doel waarmee Griekse en Latynse tekste vir 'n student in die vroeë Kerk- en Dogmageskiedenis voorgeskryf moet word. Akroterion 31.4:98-102.

Lombard, D B 1986. Teaching Greek tragedy in translation, with reference to the dramatic adaptation of the Orestes-saga by Aeschylus and Sophocles. Akroterion 31.1:13-21.

Mackay, E A 1999. Classics in South Africa: A way forward. Akroterion 44:79-90.

Malan, C A 1988. A discussion of the research done by the Human Sciences Research Council on the position of Latin as a school subject in the RSA. Akroterion 33.1:38-44.

Mans, M J 1984. Laudatio: D M Kriel. Akroterion 29.1:32-33.

1985. Latynse outeurs op skoolvlak. Akroterion 30.1/2:33-39.

Matier, K O 1983. Symposium for teachers of Latin in the Eastern Cape. Akroterion 28.1/2:43-44.

1985. Classics and constraint: The limitations of the literary approach to the teaching of Latin. Akroterion 30.1/2:29-32.

Mezzabotta, M 1984. Weskaapse Tak: Western Cape Branch. Akroterion 29.3:85. 1986. Greek tragedy for drama students: A practical approach. Akroterion 31.1:22-25.

Murgatroyd, P 1984a. Visenda modis animalia miris. Akroterion 29.3:68-72.

— 1984b. Recent CASA activities in Natal. Akroterion 29.3:85.

Saddington, D B 1985. Word - sentence - paragraph. Akroterion 30.1/2:40-41. 
Schoeman, M 1985, Die bemiddeling van groter insig in die antieke lewens- en wêreldbeskouing deur middel van 'n tematiese aanbieding van Latynse tekste. Akroterion 30.1/2:10-16.

Scholtemeijer, J 1985. Komedie as komedie. Akroterion 30.4:104-107.

Smuts, F 1983. Pliny from his letters. Akroterion 28.1 \& 2:31-34.

— 1984a. In memoriam: Suretha Bruwer. Akroterion 29.1:1-2.

— 1984b. Editorial. Akroterion 29.4:91-92.

— 1984c. Review of Lys Klassieke eiename. Akroterion 29.4:120-123.

— 1985a. In memoriam: Susanna Margaretha Bruwer, 10.10.1941-21.10.1983. AClass 28:1-4.

— 1985b. Editorial. Akroterion 30.1/2:1-2.

Swanepoel, J 1985. Grammatikale én grammatikale benaderings tot die Latynse poësie. Akroterion 30.1/2:17-28.

Van der Westhuizen, J E 1984. Sursum corda magistri et magistrae. Akroterion 29.1:30-31, 33.

Van Ryneveld, L F 1986. Seneca's Apocolocyntosis for undergraduates: Fun, learning and legal thought. Akroterion 31.1:26-30.

Van Stekelenburg, A V 1985a. Classics for the gifted. Akroterion 30.1/2:3-9.

— 1985b. Multiple translation as an aid in teaching literature. Akroterion 30.13:64-67.

Van Zyl Smit, B 1983. Love and metamorphosis in Ovid. Akroterion 28.1 \& 2:3436.

Wakerley, M F 1985. Law students like Latin: The Unitra Latin course. Akroterion 30.4:100-103.

Whitaker, R 1984. Reflections on a Homerathon. Akroterion 29.3:73-75. 